\title{
DESIGN OF A DETENTION RESERVOIR
}

\section{Katarína CIPOVOVA}

email: katarina.cipovova@stuba.sk

Research field: Flood risk, flood protection

Department of Hydraulic Engineering

Faculty of Civil Engineering

Slovak University of Technology in Bratislava

Radlinského 11

81368 Bratislava

\section{ABSTRACT}

The contribution contains the reasons for and the methods of flood protection for villages in small valleys attacked by flash floods, which cause high economic, cultural and social damage. One of the possible solutions is to build a detention reservoir, which has to retain the flood wave and prevent an odd amount of water from flowing out of the river bed. In this paper a model example is given. The aim of the example is to show (according to hydrological data) how to design the dimension parameters of the dam, i.e. the height of the dam, the outlet structure capacity, the spillway capacity, the stilling basin and the necessary river bed lining. Attention is paid to stability problems, as well.

\section{KEY WORDS}

- flood protection,

- detention reservoir,

- hydraulic design,

- spillway,

- outlet.

\section{INTRODUCTION}

Floods are a natural part of the hydrologic cycle. In some countries man can exploit overflowing water to his benefit; in other places he fights against it unceasingly. What is the basic cause of a flood? Each flood is unique and has different causes; however, they can basically be divided into five groups:

1. long-lasting precipitation covering a large area

2. short intensive storms

3. snow melt

4. natural or artificial reduction of a cross-section area ( ice barrier, trees, ...)

5. failure of a water structure

Floods have many negative effects. Their primary effects include physical damage (damaged structures, bridges, sewage systems, buildings, cars, etc.) and casualties (people and livestock die due to drowning or subsequent epidemics and diseases). Their secondary effects include, e.g. contamination of water, unhygienic conditions, the death of intolerant species of flora; and their tertiary effects include long-term economic effects.

There are many flood protection methods, both active and passive. But we cannot generalize their application, because each locality is different and many parameters affect the design.

Minimizing flood risk can be achieved in three ways:

1. decreasing the accumulated discharge. This can be provided by water structures, weir dams, detention reservoirs or flooding less valuable parts of a region.

2. increasing the capacity of a water course

3. instituting corrections and arrangements in the flooded area (e.g. planning, warning, rescue services, etc.).

Flood protection is realized on bigger streams and rivers by 


\section{SIOYASTODSILA \\ O)

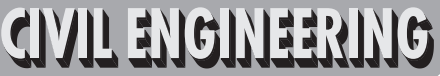

2011/1 PAGES $33-40$

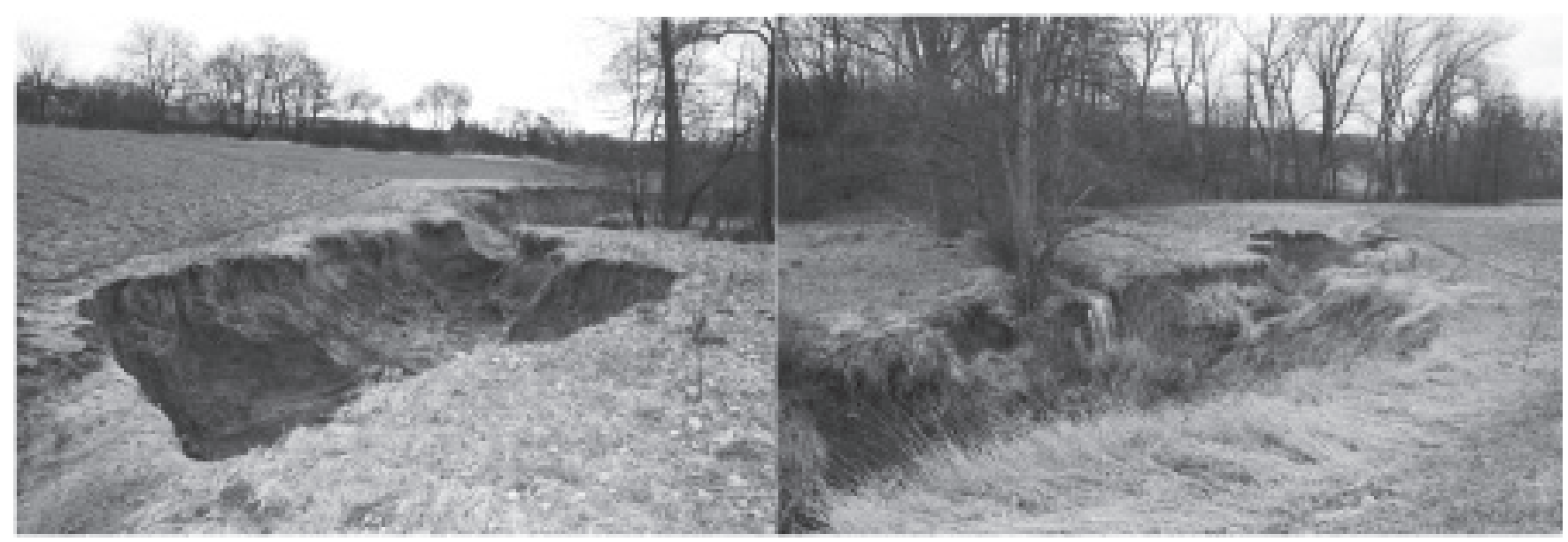

Fig. 1 Erosion - typical consequence of a flash flood.

dikes and water schemes, but such solutions are ecologically and economically impossible on small streams. Therefore, building a dry detention reservoir is a very progressive solution nowadays. It is an effective water structure, which has no noisy effects on the environment and can even be an aesthetic part of the countryside. It has to retain the flood wave and prevent an odd amount of water from flowing outside the river bed. A village can be protected against the static impacts of the water (overflowing) as well as the dynamic impacts (erosion, sediment transport and damage to roads and bridges).

A model example of a planned detention dam on the Adamovský Creek in the Trenčín region of Slovakia is shown in this paper. The basic principles and methods of such a solution are shown.

\section{INPUT DATA FOR A FLOOD PROTECTION DESIGN}

There are many input data for a flood protection design, especially:

- description of the place (city/town) (location, number of inhabitants, monuments, relics, nature reserves, springs, wetlands, etc.)

- character of the site (description of the catchment, land use, inclinations, length of the stream, objects on the stream, etc.),

- map data

- hydrologic data (rainfall, runoff and temperature data. In this project (design) these data were used from the Trenčín gauging station. The design flood wave was calculated from information about the catchment, land use, temperatures, rainfall and runoff.),

- geological, pedologic and morphological data [1] (information about the bedrock, landslides, types of soil, etc.)
- geodetic data (information about existing geodetic points, topographical survey of the area)

- hydraulic data (roughness of the stream, slope, capacity of any structures)

\section{DESIGN METHOD}

The maps had to be converted and adjusted according to our requirements. Then the profile of the planned dam had to be chosen. A dam has to be built about $350 \mathrm{~m}$ above a bridge in a village in order to provide enough space to retain water, but not to endanger any people or buildings.

Afterwards, the design flood wave, i.e. the retention volume of the dam had to be calculated. There are various ways to get that input, either from SHMÚ (Slovak Hydrometeorological Institute) or using some rainfall-runoff models. Our design flood wave was calculated using DesQ 5.2. software by the $\mathrm{CN}$ numbers method. CN numbers represent the runoff from a catchment. This method uses information about rainfall and runoff, land-use and the morphology of a catchment. In this case designed rain was used, and its intensity had a value of $0.25 \mathrm{~mm} / \mathrm{min}$. The rain lasted 5 hours.

The designed flood wave of the Adamovský Stream has a culmination of $Q_{100}$ of $7.2 \mathrm{~m}^{3} \cdot \mathrm{s}^{-1}$. The time of the rising of the flood wave is 4 hours; the time of the recession is 9 hours. The volume of the flood wave is $140,000 \mathrm{~m}^{3}$. The designed flood wave is shown in Fig. 2. The retention volume of the dam is represented by ABC in Fig. 3. Point $\mathrm{C}$ indicates the capacity of the channel under the dam $Q_{K}$ (calculated later).

In the first step it is useful to match point $\mathrm{A}$ with $\mathrm{C}$ by a straight line and simply measure $\mathrm{ABC}$, which represents the provided retention volume of the dam (here, $56,200 \mathrm{~m}^{3}$ ). 


\section{IDYALS JOUSSIAL \\ of

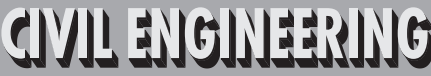

2011/1 PAGES $33-40$

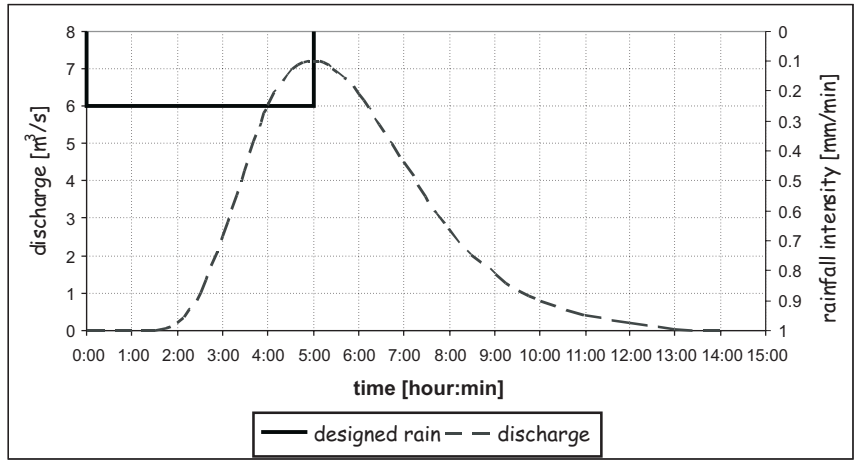

Fig. 2 Designed flood wave with a culmination of $7.2 \mathrm{~m}^{3} . \mathrm{s}^{-1}$. In this case the designed rain has an intensity of $0.25 \mathrm{~mm} / \mathrm{min}$ and lasts 5 hours.

The required height of the dam can be subtracted from the reservoir's storage elevation curve (Fig. 4). To ensure the required retention volume of $56,200 \mathrm{~m}^{3}$, the dam on this stream should be at least $5 \mathrm{~m}$ high.

The values of the retention surfaces and retention volumes belonging to the various heights of the dam are shown in Table 1.

There are two basic types of material used for such structures: earthfill dams (Fig. 5 left) made of local materials (soil, clay, dirt, sand, etc.) or solid gravity dams (Fig. 5 right) (concrete, stone, etc.). The material for this dam is designed to be concrete with a quarry stone lining.

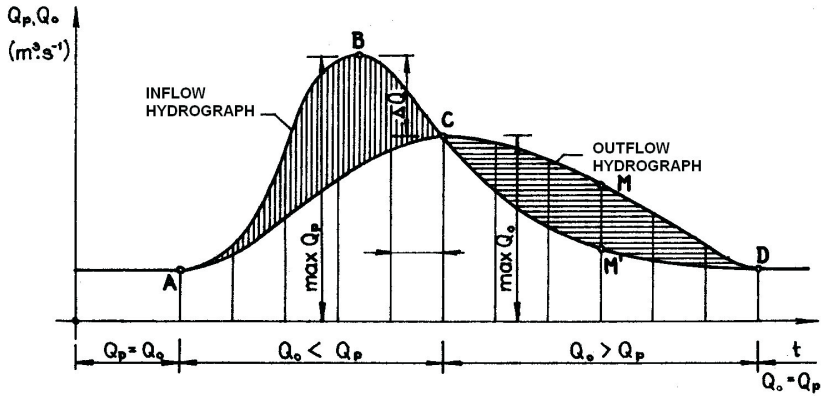

Fig. 3 Attenuation and lagging of the routed hydrograph. Inflow $Q_{P}$ and outflow $Q_{O}$ hydrographs. $Q=f$ (time). The water entering the storage is hatched vertically; the water leaving the storage is hatched horizontally.

\section{RATING CURVE}

The calculation of the discharge in the Adamovský Stream (Fig. 6) was performed using Chézy's formula (1), which provided uniform flow [5].

$$
\begin{aligned}
& Q=C \cdot S \sqrt{R \cdot i_{o}} \\
& C=\frac{1}{n} \cdot R^{\frac{1}{6}}
\end{aligned}
$$
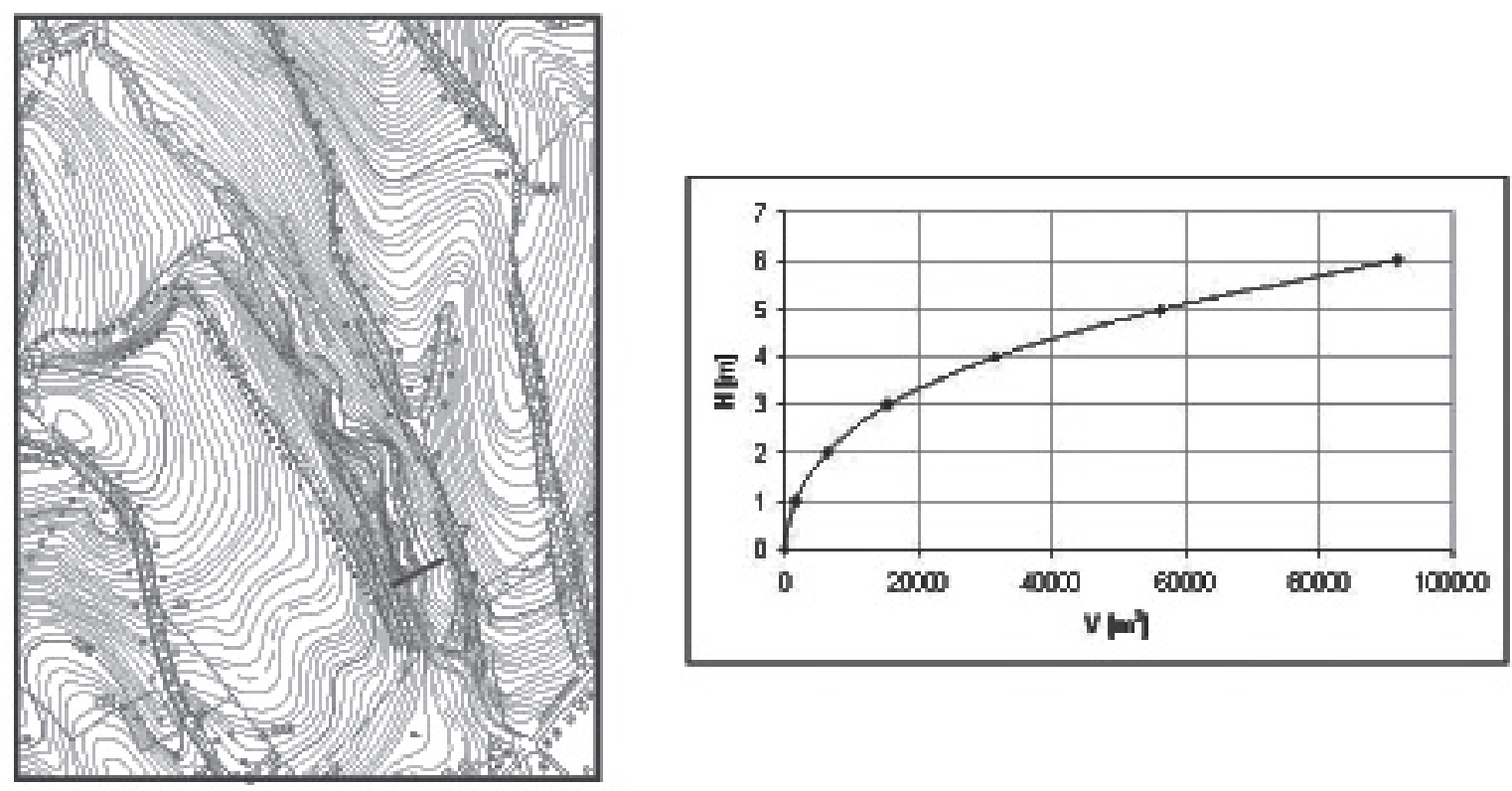

Fig. 4 Reservoir storage elevation curve; the volume of the retention space V depends on the height of the dam $H$. 


\section{SIOYAHYJOUSILL \\ O)

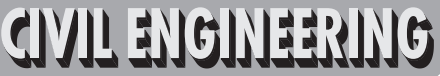

2011/1 PAGES $33-40$

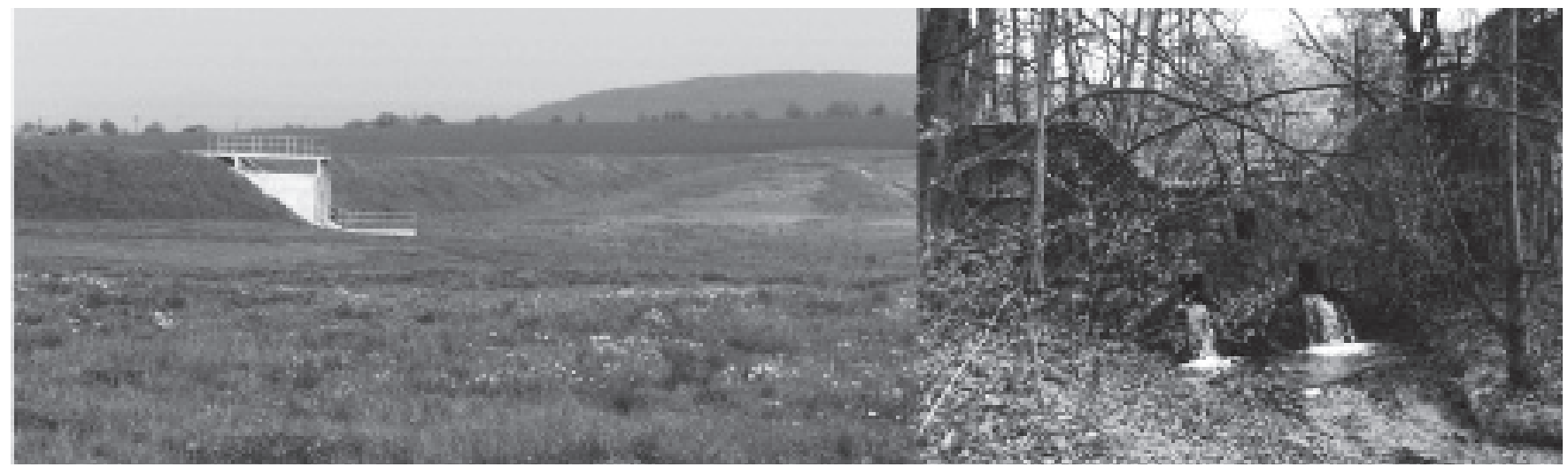

Fig. 5 Earth-fill dam (left) and solid gravity dam (right).

Tab. 1 Reservoir surfaces and volumes according to the height of the dam on the Adamovsky Stream in the village of Adamovske Kochanovce.

\begin{tabular}{|c|c|c|}
\hline $\begin{array}{c}\text { Height of a dam } \\
{[\mathbf{m}]}\end{array}$ & $\begin{array}{c}\text { Reservoir surface S } \\
{[\mathbf{m} \text { 2] }}\end{array}$ & $\begin{array}{c}\text { Reservoir volume } \\
{[\mathbf{m} 3]}\end{array}$ \\
\hline 0 & 0 & 0 \\
\hline 1 & 3198.5 & 1599.2 \\
\hline 2 & 6397.0 & 6397.0 \\
\hline 3 & 11514.6 & 15352.8 \\
\hline 4 & 20726.2 & 31473.1 \\
\hline 5 & 28914.4 & 56293.4 \\
\hline 6 & 42220.1 & 91860.6 \\
\hline
\end{tabular}

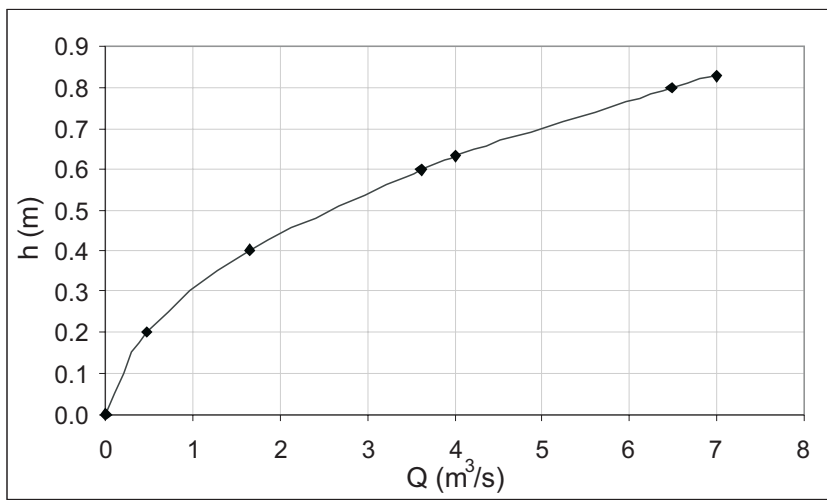

Fig. 6 Rating curve. Discharge $Q$ depends on the depth of the water in the downstream channel $h$. where $R$ is the hydraulic radius $\mathrm{S} / \mathrm{O}(\mathrm{m}) ; \quad S$ is the cross-sectional area $\left(\mathrm{m}^{2}\right) ; O$ is the wetted perimeter $(\mathrm{m}) ; n$ is Manning's roughness coefficient; $i_{0}$ is the longitudinal slope (-) and $C$ is Chézy's coefficient $\left(\mathrm{m}^{0,5} \cdot \mathrm{s}^{-1}\right)$. The designed channel's cross section is a trapezoid with a bottom width of $\mathrm{b}=1 \mathrm{~m}$, bank slopes of $1: 2(\mathrm{~m}=2)$ and a longitudinal slope of $i_{o}=1.9 \%$. The hydraulic roughness is entered by Manning's roughness coefficient $n=0.033$ (which means the bank fortification is, for example, quarry stone).

\section{DOWNSTREAM CHANNEL'S DISCHARGE CAPACITY}

It is necessary to find a critical cross section (area with the lowest capacity) on the channel. There are potentially three critical places under the designed dam: the culvert under the bridge with a capacity of $11.2 \mathrm{~m}^{3} \cdot \mathrm{s}^{-1}$, the pipe under the village with a capacity of 4.48 $\mathrm{m}^{3} \cdot \mathrm{s}^{-1}$, and the spillway of the anti-fire retention dam with a capacity of $11.96 \mathrm{~m}^{3} \cdot \mathrm{s}^{-1}$. The lowest value mentioned above is $4.48 \mathrm{~m}^{3} \cdot \mathrm{s}^{-1}$; therefore, the channel capacity discharge $Q_{K}=4.0 \mathrm{~m}^{3} \cdot \mathrm{s}^{-1}$ for the river bed under the dam was designed. Then the maximum water depth in the river bed is $0.63 \mathrm{~m}$ (from the rating curve in Fig. 6).

\section{BASIC PRINCIPLES FOR DESIGN OF THE FUNCTIONAL STRUCTURE (OUTLET, SPILLWAY AND STILLING BASIN)}

The water outlet of every detention dam must be hydraulically solved and shape-designed so that:

- the discharge is automatically secured until the water level touches the spillway crest 


\section{IDYALS JOUSSIAL \\ of

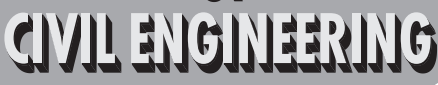

2011/1 PAGES $33-40$

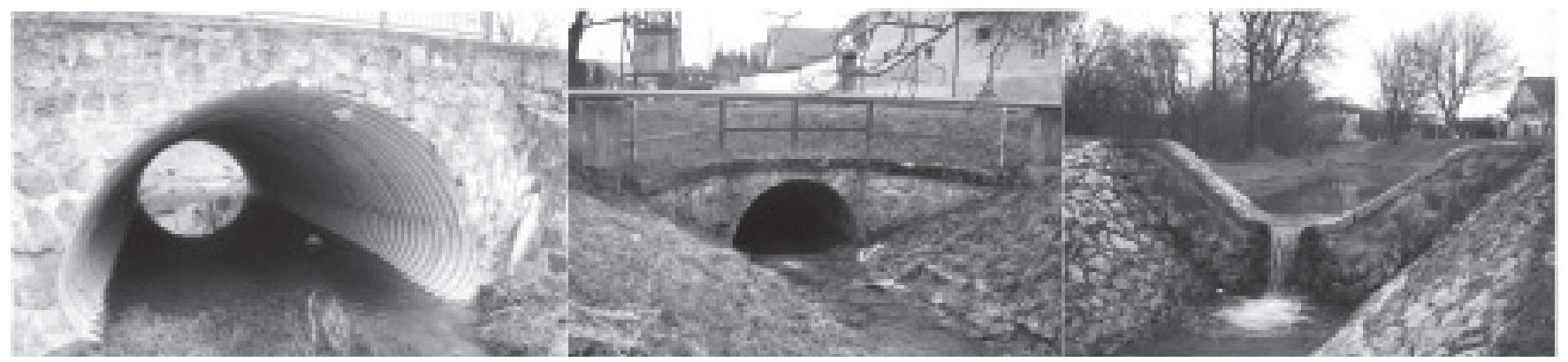

Fig. 7 Three critical points downstream: culvert, pipe and the spillway.

- the flood discharge is safely carried away without overflowing the dam

- the outlet contributes to the transformation of the flood wave and a decrease of the culmination discharge

By following the conditions and knowledge obtained from the hydrotechnic research, the principles below are valid for such types of structures [3]:

a) for design of an outlet:

- shape - a barrier in a stream should not be created,

- width: rectangle - if the capacity conditions allow, the width of the outlet should equal the width of the bottom of the downstream channel,

trapezoid -the shape of the downstream channel should be copied. This recommendation can be ignored in the case of high dams where the capacity of the outlet is relatively big,

- the height (or both dimensions - height and width) is proposed following the condition: the outflow from the full dam (the water level in the dam equals the level of the spillway crest) equals the capacity of the downstream channel $Q_{o}=Q_{K}$,

- round the edges to eliminate turbulence and lower reductions in the lateral area,

b) for design of the spillway:

- spillway surface - under pressure,

- ground plan of the spillway - across the stream or circular on the plan (for a higher discharge)

- width of the spillway crest- size to $\left(Q_{500}-Q_{o, \max }\right)$ or $\left(\mathrm{Q}_{100}\right.$ $\left.50 \% Q_{o, \max }\right)$,

- the points where the spillway meets the slopes of the dam should be properly fortified with quarry stone.

c) for design of the stilling basin:

- according to hydraulic research of the hydraulic jump, the designed discharge under the functional object should equal the maximum discharge through the object,

- dimensions of the stilling basin - apply the so-called general method based on the energy head,

- stone fortification below the stilling basin,

d) for other arrangements:

- stabilizing the flow conditions downstream on the necessarily required length,

- upstream - fortifying the bottom and slopes with 20-30 cm pebbles seems to be sufficient,

- concentrating the flow into the stilling basin to prevent the water from overflowing onto the floodplain.

The basic signatures used in the calculations are:

- ground elevation of the river bed above and below the dam KDP = KDT [m a. s. l.]

- water level in the dam $K H$ [m a s. s. l.]

- water level in the channel under the dam $K D$ [m a. s. l.]

- maximum water level in the dam $K H_{\max }$ [m a .s .l.]

- level of the spillway crest $K P$ [m a. s. l.]

- elevation of the upper edge of the outlet KHO [m a .s .l.]

- designed discharge $Q_{100}\left[\mathrm{~m}^{3} \mathrm{~s}^{-1}\right]$

- channel capacity discharge $Q_{K}\left[\mathrm{~m}^{3} \mathrm{~s}^{-1}\right]$

The spillway was designed in a trapezoidal shape: a bottom width of $2 \mathrm{~m}$, a height of $1 \mathrm{~m}$ and a bank slope of $1: 1$. The capacity of the spillway was calculated using general Dubuat's equation for a spillway (4) as follows

$Q_{P}=\frac{2}{3} \mu_{p} \cdot \sqrt{2 g} \cdot\left(\frac{b}{h}+\frac{4}{5} m\right) \cdot h^{5 / 2}$

It was conceived that $Q_{O}=Q_{K}$ (the outflow matches the capacity of the channel under the dam), which is the basic anticipation for 
designing a detention reservoir. The width of the outlet $b_{o}$ is $1 \mathrm{~m}$ and height $\mathrm{a}_{\mathrm{o}}$ is $0.66 \mathrm{~m}$ (from the outlet equations) [3].

$$
a_{o}=\frac{Q_{K}}{\mu_{v} \cdot b_{o} \sqrt{2 g \cdot H}}
$$

The outlet capacity had to be calculated for 3 situations:

1. The water level is lower than the upper edge of the outlet; this event is solved as a discharge over broad-crested weirs expressed by the following equation [3]

$$
Q_{o}=\varphi \cdot b_{o} \cdot h_{1} \sqrt{2 g\left(h_{0}-h_{1}\right)}
$$

where $h_{1}=K H-K H O$ and $h_{0}$ is the water level in the dam $K H$ above the bottom edge of the outlet; counted with the velocity head (7), and $\varphi$ is a coefficient of the overfall discharge.

$$
h_{0}=z+\frac{\alpha \cdot v_{0}^{2}}{2 g}
$$

2. The partially submerged orifice was calculated as the total of the free and submerged outlets as follows:

$$
Q_{o}=\mu_{v} \cdot b_{o} \sqrt{2 g}\left[\frac{2}{3}\left(H^{\frac{3}{2}}-h_{1}^{\frac{3}{2}}\right)+y_{d} \sqrt{H}\right]
$$

where $h_{1}=K H-K H O, H=K H-K D$ and $y_{d}$ is the water depth under the dam. The orifice coefficient $\mu_{v}$ was calculated from [3]:

$\mu_{v}=-0,3376\left(\frac{h_{1}}{H}\right)^{2}+0,3772\left(\frac{h_{1}}{H}\right)+0,6104$

3. The submerged orifice discharge was calculated from

$$
Q_{o}=\mu_{v} \cdot a_{o} \cdot b_{o} \sqrt{2 g \cdot H}
$$

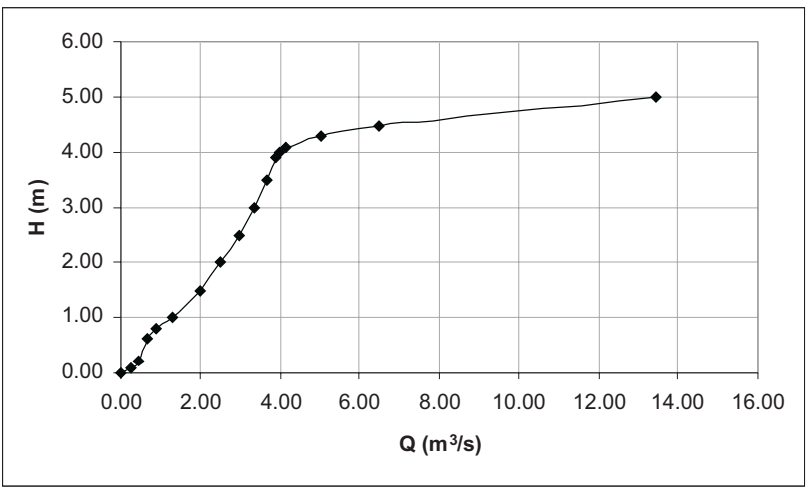

Fig. 8 Rating curve of the whole structure.
The flowing through the dam during a flood situation is characterized by the rating curve of the complex structure (the outlet and overflow together), $Q=Q o+Q_{P}=f(H)$ (Fig 8).

The stilling basin is the most common form of energy dissipater converting the supercritical flow from the spillway into a subcritical flow compatible with the downstream channel regime. However, in this case the supercritical flow occurs under the dam. The critical depth in the channel was calculated, and its value is $0.71 \mathrm{~m}$, but the water depth from the rating curve is only $0.63 \mathrm{~m}$. A stilling basin with minimum parameters $(0.3 \mathrm{~m}$ deep, $4 \mathrm{~m}$ wide and $5 \mathrm{~m}$ long $)$ was designed, only due to functional reasons.

\section{TRANSFORMATION OF A FLOOD WAVE}

The effectiveness of a detention reservoir is usually proved by calculation of a flood wave's transformation.

The transformation of a flood wave means the reduction of a culmination discharge - flattening and extension of a flood wave peak (Fig. 9) [5]. This can be done numerically using several types of software or graphically. In this case the calculation of the transformation was performed graphically by Klemeš' method. The principle of the calculation is in equation (10).

$\left(Q_{p}-Q_{o}\right) d t=S . d H=d V$

That means that in a very short period of time, there is some inflow and some outflow, and their difference causes a change in the water level or the volume of the water in the dam.

Building a detention reservoir on Adamovský Stream lowered the dangerous culmination discharge from $7.2 \mathrm{~m}^{3} \cdot \mathrm{s}^{-1}$ to $4 \mathrm{~m}^{3} \cdot \mathrm{s}^{-1}$.

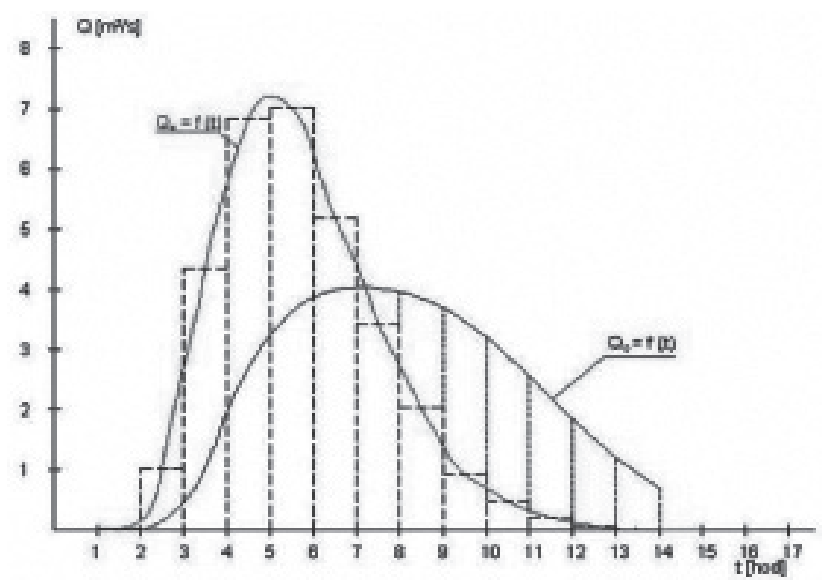

Fig. 9 Transformation of a flood wave on Adamovský Stream by a retention dam. 


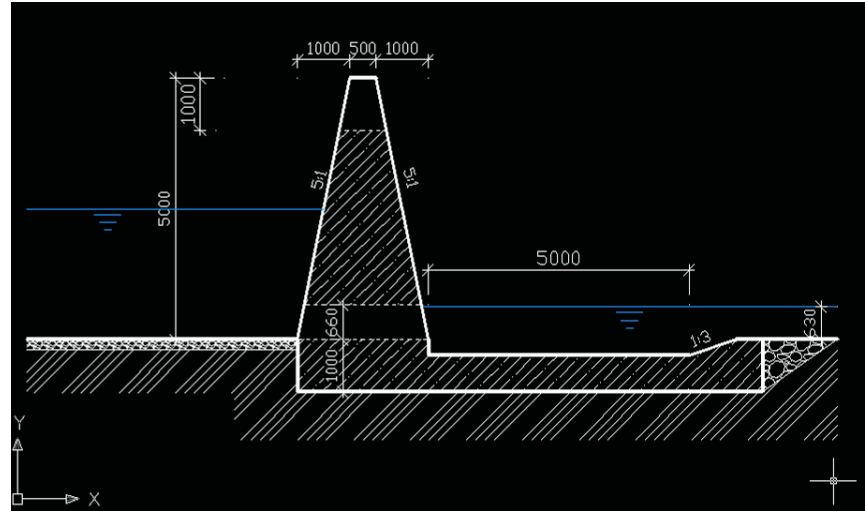

Fig. 10 Scheme of the designed detention reservoir on the Adamovsky Stream.

Tab. 2 Soil parameters.

\begin{tabular}{|c|c|c|c|c|c|}
\hline soil name & & & \multicolumn{2}{|c|}{ clay } & gravel \\
\hline soil type & & & \multicolumn{2}{|c|}{ F8 } & G4 \\
\hline symbol & & & \multicolumn{2}{|c|}{$\mathrm{CH}$} & GM \\
\hline & mark & unit & $\min$ & $\max$ & \\
\hline specific weight & $\gamma$ & $\mathrm{kN} \cdot \mathrm{m}^{-3}$ & 20 & 21 & 19.5 \\
\hline $\begin{array}{l}\text { angle of internal } \\
\text { friction }\end{array}$ & $\varphi$ & $\circ$ & 15 & 19 & 28 \\
\hline cohesion & $c$ & $\mathrm{kPa}$ & 10 & 20 & 2 \\
\hline $\begin{array}{l}\text { deformation } \\
\text { modulus }\end{array}$ & $E_{\text {def }}$ & $\mathrm{MPa}$ & 4 & 6 & 60 \\
\hline
\end{tabular}

\section{STABILITY}

According to the visual geological inspection, there are two types of soil: clayey gravel (GM) and clay with high plasticity $(\mathrm{CH})$. Inasmuch as we do not know the exact parameters, the stability was calculated for more values. The exact results will be known only after a detailed geological survey.

The slope stability was solved by Geo5 software using the methods of Bishop, Petterson and Sarma. The slopes are unstable for the most dangerous situation - an empty dam after a flood, so a gabion fortification was suggested.
Side-tilt stability is satisfying, but stability against a horizontal movement is not; therefore, a stabilizing tooth has been designed in the footing bottom.

The consolidation settlement was also calculated for all the values. Load $\sigma$ is $174.99 \mathrm{kPa}$, and the ground bearing capacity R will be subtracted from the charts after the geological survey.

\section{CONCLUSIONS}

Since the 1990s an increase in total maximum daily precipitation has been noticed. Analyses of hydrological and meteorological situations prove that floods on such catchments are caused by heavy rains with a high intensity at the upper part of a catchment.

The solution described in the article reduces the culmination and protects the village against flood events. This dam is designed to retain a flood with a 100-year frequency. Channel arrangements downstream keep the water from flowing out of the channel and prevent the creation of scours. Quarry stone fortification of the channel river bed prevents backward erosion and clogging of the anti-fire retention dam, but it does not affect the groundwater.

The dam is designed as a concrete structure $5 \mathrm{~m}$ high, with an outlet structure in the bottom, which is $1 \mathrm{~m}$ wide and $0.66 \mathrm{~m}$ high. It has a trapezoidal spillway, which is $2 \mathrm{~m}$ wide and $1 \mathrm{~m}$ high. The unstable slopes are fortified with gabions [2], [7]. The dam will be made of natural materials; it should become an aesthetic part of the countryside. The total costs of such a project can reach $600,000 €$ (18 mil. SK).

The next phase of this project consists of a detailed topographical and geological survey, creating a DTM (digital terrain model), modelling a flood situation using, for example, MIKE 11 and MIKE 21 software, and drawing the flood maps. A flood map is a very good way to present the results to village governments and the public. Such solutions are often supported by European Union funds.

During the planning, many problems can appear. Usually the biggest problem is purchasing detailed input data. Small streams such as the Adamovský Stream are not usually monitored; there is no information about n-year discharges or rainfall intensities and there is no topographical survey realized. This means that in the first phase of the project, we will have to rely on uncertain or sometimes even estimated values, which will come into the calculations. 


\section{REFERENCES}

- Atlas of the countries of the Slovak Republic (Atlas krajín Slovenskej republiky, MŽP Bratislava), Ministry of the Environment, Bratislava, Slovakia (2002).

- Hulla, J., Turček, P.: Foundation engineering (Zakladanie stavieb), JAGA group, s. r. o., Bratislava, Slovakia (2004).

- Kamenský, J.: Hydraulic design of detention reservoir outlet structures. Final report. (Hydraulický návrh výtokových objektov z poldrov. Záverečná správa), Department of Hydraulic Engineering, Faculty of Civil Engineering, Bratislava, Slovakia (2001).
- Lukáč, M., Bednárová, E.: Reservoirs and dams. Design and operation. (Nádrže a priehrady, navrhovanie a prevádzka), STU Bratislava, Slovakia (2001).

- Mäsiar, E., Kamenský, J.: Hydraulics II. (Hydraulika II), Bratislava, Slovakia (2001).

- Floods before, during and after... (Povodne pred, počas, po ...), SHMÚ Bratislava, Slovakia (2003).

- STN 731001 Základová pôda pod plošnými základmi (1987). 